\title{
ПОСЛОВИЦЫ О СЕЛЬСКОХОЗЯЙСТВЕННОМ ОБИХОДЕ В СЛАВЯНСКИХ ЯЗЫКАХ
}

\section{Proverbs About Agricultural Life in Slavic Languages}

Keywords: proverbs, agriculture, elementary school, students, everyday life

Contact: МГПУ; sadova.alena@mail.ru

Проблема происхождения языка безусловно является актуальной в современном мире, когда остро обсуждаются вопросы нашей истории, ее правдивости и значимости для человечества в целом.

У каждого народа есть свой язык, со своими нормами, правилами, и каждый народ считает его уникальным. Но есть в наших языках нечто общее, нечто, что показывает нам общую историю их происхождения. И для того, чтобы увидеть это, необходимо обратиться к самым истокам, а помочь нам в этом может фразеология.

\section{Происхождение фразеологии}

Фразеология как наука, как лингвистическая дисциплина была сформирована под влиянием Ч. Балли, швейцарского ученого, который занимался французской стилистикой и впервые указал на два типа устойчивых выражений фразеологические ряды и фразеологическое единство.

Французские лингвисты не интересовались его идеями, но тем не менее они стали основой фразеологии в России. В исследованиях Е. Д. Поливанова и В. В. Виноградов, теория Ч. Балли получила переработку относительно русского языка.

Особый вклад в развитие русской фразеологии внес советский лингвист академик Б. А. Ларин. Сначала он обратил внимание на необходимость перехода от описательной фразеологии к исторической фразеологии, подчеркнул, что изучение стиля фразеологических единиц и их этимологии заслуживают особого внимания. 
В последующие десятилетия эти направления исследований, изложенные Б. А. Лариным, были воплощены в трудах его последователя, профессора Ленинградского университета В. М. Мокиенко, который обозначил новые направления в развитии фразеологии.

Учитель начальной школы должен широко использовать в своем творчестве произведения народного творчества: сказки, загадки, пословицы, поговорки; рассматривать устный фольклор как средство выражения мировоззрения народа, богатый духовный источник, в котором подлинно отражается народная жизнь, черты русского народного характера.

Говоря о пословицах и поговорках, нельзя не вспомнить о заслугах В. И. Даля. В. И. Даль видел в пословицах прежде всего образцы живой русской речи, народного способа выражения, в отличие от «безличной и бесцветной» речи образованных людей. В. И. Даль волновался, что развитие образования и повышение уровня образования «избегают прямой русской речи и всего, что с ней связано». Отсюда такое внимание к народной речи и такое ее изобилие в словаре. Сборник пословиц В. И. Даля остается непревзойденным в полноте материала, представленного в нем; это незаменимый источник паремиологической информации для любого исследователя.

Лингвисты всех времен, изучавшие пословицы, рассматривали их прежде всего как этнокультурный феномен. Ф. И. Буслаев видел в них «произведения исконного слова, выражающие жизнь людей, их здравый смысл и нравственные интересы». А для И. М. Снегирева пословицы стали «мирской мудростью в фигурных облачениях». Этнограф подчеркнул, что пословицы «составляют мирское предложение, общее мнение, одно из тайных, но сильных, изначально означающих родство человечества с образованием и объединением умов и сердец».

Для В. И. Даля культурный аспект пословиц также был важен: «Коллекция пословиц - это собрание популярной экспериментальной мудрости и суеверия; это цвет национального разума, оригинальная статья; это обычная народная правда, своего рода судебный человек, никем не осужденный. Однако, характеризуя пословицу, Даль также рассматривает ее с лингвистической точки зрения, указывая прежде всего на ее структурные и семантические особенности. По словам Даля, пословицы гласят: Это целые изречения, сбитые одним куском, в одной комнате» (Даль 2000). Т. е. они имеют структуру предложения и имеют структурно-семантическую целостность и стабильность. Наличие переносного значения В. И. Даль считал самым важным признаком пословицы. 
Сборник В. И. Даля представляет русское пословичное богатство, без которого невозможно серьезно изучать русский язык в целом, а также другие славянские языки. Благодаря коллекции В. И. Даля, пословицы стали интересны не только фольклористам и этнографам, но и лингвистам. Славянская паремиология могла быть сформирована и выделена в самостоятельный раздел лингвистики только после определения предмета и основных понятий. И заслуга в этом В. И. Даля неоспорима.

Ученые до сих пор не знают достоверно, в какой момент славяне выделялись из индоевропейских племен и, соответственно, до славянского языка из индоевропейского языка. Даты варьируются от XV до V века до нашей эры.

Эффективное использование пословиц привлекает внимание «Русской азбуки» В. Г. Гогорецкого, в которой представлено около 90 паремий. В содержательном плане они различаются по тематическому разнообразию:

- учение (Учение - путь к умению);

- дружба (Нет друга - ищии, а нашел - береги);

- труд (Всякий человек в деле познается);

- природа (Сентябрь холоден, да сыт);

- нравственные качества человека.

Картинность, живописная форма, способность рисовать жизнь, не прибегая к описаниям и стремление к наиболее яркой выразительности позволяет пословице сравнивать объекты или явления через сравнение.

\section{Деление славянских языков}

Когда протославянский язык начал распадаться на ветви, лингвисты определяют гораздо точнее. По их оценкам, распад протославянского языка произошел в 500750 гг. Язык разделен на восточную, южную и западную ветви. Западные и южнославянские языки сразу стали развиваться на отдельные языки, т. е. польский, чешский и т. д.

Древнерусский считается правосточноевропейским языком, который впоследствии был разделен на русский, украинский, белорусский и несколько тупиковых диалектов, которые не сохранились до наших дней.

Современное разделение славянских языков выглядит следующим образом: восточнославянские: русский, белорусский, украинский и русинский; 
западнославянские: польский, чешский, словацкий, кашубский, верхнелужицкий и нижнелужицкий; южнославянские: болгарский, македонский, сербский, хорватский, боснийский, черногорский и словенский.

От одного славянского языка нас отделяют всего около тысячи лет. Мы все произошли от одного народа. Благодаря этому у нас, славян, по-прежнему очень похожий культурный и языковой код.

Это хорошо видно на примере некоторых довольно распространенных пословиц из разных славянских языков, которые имеют аналоги в русском фольклоре:

\begin{tabular}{|c|c|}
\hline $\begin{array}{l}\text { Любиш погоняти - люби й коня } \\
\text { годувати. (укр.) }\end{array}$ & $\begin{array}{l}\text { Любишь кататься, люби и саночки } \\
\text { возить. }\end{array}$ \\
\hline $\begin{array}{l}\text { Mowa jest srebrem, milczenie złotem. } \\
\text { (пол.) }\end{array}$ & Слово - серебро, молчание - золото. \\
\hline $\begin{array}{l}\text { Ако не посееш нещуо, няма да ожънеш } \\
\text { нищь. (болг.) }\end{array}$ & Что посеешь, то и пожнешь. \\
\hline Imeti glavo v oblakih. (словен.) & Витает в облаках. \\
\hline Mi̊j di̊m - můj hrad. (чеш.) & Мой дом-моя крепость. \\
\hline
\end{tabular}

Как мы видим, даже не зная основ прочих славянских языки, мы можем понять примерный смысл пословиц.

\section{Изучение пословиц и поговорок в школе}

Правильное использование пословиц и поговорок придает речи выразительность, особый эмоциональный цвет и выразительность. Обычно это показывает уровень культуры речи человека, его образование.

Пословицы и поговорки занимают особое место среди других жанров народного творчества. Они широко используются не только в устной речи, но также в художественной литературе, журналистике и средствах массовой информации, где они постоянно подвергаются семантическим изменениям и различным структурным преобразованиям. 
Использование пословиц и поговорок при обучении русскому языку позволяет использовать их не только для объяснения многих грамматических явлений, но и для обогащения лексического запаса.

Притчи и поговорки можно использовать в упражнениях для развития речи, в которых они используются в качестве стимула. Одну и ту же поговорку или поговорку можно толковать по-разному. Поэтому, основываясь на этой пословице или пословице, студенты учатся выражать свои собственные мысли, чувства, переживания, т. е. демонстрируют различные способы помещения их в речь. Поэтому использование пословиц и поговорок в уроках русского языка развивает творческую инициативу студентов через подготовленную и неподготовленную речь.

В начальной школе работа сводится к активному знакомству учащихся с пословицами, их запоминанию. Учитель должен помочь детям раскрыть значение пословиц и уметь применять их в своей речи.

В уроках чтения пословицы помогают обобщить усвоенное, кратко изложить мораль и сформулировать основную идею прочитанного.

Притчи и поговорки отражают всю многогранную жизнь людей, сферы их деятельности, сложность и противоречия жизни. Главным героем в этом жанре всегда является человек в разных его «ипостасиях». Пословицы и поговорки обобщают многовековой жизненный опыт людей, содержат эмоциональную оценку действий человека, событий, которые с ним происходят, природных явлений.

Поговорки о сельском хозяйстве также активно пополняются: Удобряйте больше земли - урожай будет выше:

- Там нет плохой земли, есть плохие пахари;

- Скот гладь не рукой, а мукой;

- Kто не сеет, тот и не пожинает.

Важнейшими чертами русского этноса являются человеколюбие и терпимость, тематическая группа по труду широко представлена в пословицах и поговорках. Как правило, в паремиях труд изображается яркими красками, но бывает, что люди демонстрируют свои идеалы через противоположность, т. е. иронию или насмешку над глупостью и бездельниками. 
Пословицы стали широко распространены в связи с тем, что в них были заложены определенные жизненные закономерности и восприятия, поскольку они изучались в виде готовых суждений, выводов, заключений.

Много было сказано о труде и промышленности. Это неудивительно: человек работал на природе. Дело в том, что человеческая цивилизация - это двигатель прогресса, это все, что нужно для развития интеллекта, обеспечения комфорта, безопасности и глобального самосохранения человека как биологического вида. Семья и дети не могут забыть о том, что им нужно помогать людям и вдохновлять всех, кто встречался по пути, плодотворно работать.

Сельское хозяйство всегда было благородно для появления народных афоризмов. Это не только благополучие, но и жизнь всей семьи. В каждой русской семье есть дети, которые стремятся жить в мире, любить людей, всегда быть уверенными в себе, паразитировать и обманывать.

Например, в агрономической и кооперативной пропаганде 1920-х гг. популярные пословицы и поговорки были широко использованы. До революции 1917 г. земства, кооперативы, сельскохозяйственные общества занимались агрономической и кооперативной пропагандой. Считается, что в контексте развития сельского хозяйства практические советы по улучшению сельского хозяйства, подкрепленные примерами из народной мудрости, легче воспринимаются крестьянством. Редактирование контента было предложено авторами книг о сотрудничестве и продвижении совместных идей. Рабочие кооператива, пытаясь привлечь крестьян в кооператив, в популярные брошюры и тексты народных афоризмов, давали названия книг в виде народных пословиц (ср. «Копейка рубль бережет» (1905), «Копейка рубль бережет, а рубль голову стережет» (1913), «Хозяйство без рубля что корабль без руля» (1917) и др.).

С помощью земских агрономов передовые крестьяне стали понимать, что «возможность получить два колоса там, где раньше рос один, не одни только пустые разговоры». Ведь «недаром говорят - Ум хорошо, а два лучше: невозможное для одного становится доступным для многих соединившихся вместе для достижения вместе». Именно таким крестьянским союзом были сельскохозяйственные общества, занимавшиеся распространением среди крестьян знаний по сельскому хозяйству. Основная задача сельскохозяйственных обществ состояла в том, чтобы улучшить прием и переработку сельского хозяйства, чтобы «два колоса росло там, где раньше был один». Каждый Крестьянин должен был выяснить, что нужно сделать все, чтобы перестроить свое хозяйство, сделать его выгодным и доходным. 
Многие пословицы о труде сосредоточены на том факте, что вы не можете кормить без труда. Они появились в то время, когда люди жили в сельском хозяйстве. Теперь их значение интерпретируется несколько иначе: если ты не работаешь, то получаешь зарплату. Вот некоторые из этих пословиц:

-Без труда не вытащчишь и рыбку из пруда.

- Труд человека кормит, а лень портит.

- Пот на спине - так и хлеб на столе.

- Там и хлеб не родится, где кто в поле не трудится.

Люди верили, что человек, не знающий прелести физического труда, никогда не будет счастлив. Люди, которые сознательно прятались от работы, избегали и презирали. Поэтому они сказали: там, где есть труд, там и счастье.

Поговорки о труде, в котором его сравнивают с богатством, особенно актуальны сегодня. Если все понимают, что во имя успешного будущего должна быть проделана кропотливая работа, в мире исчезнет зависть, гнев, уменьшится количество грабежей, краж и, самое главное, бедности - бедность можно преодолеть.

Часто пословицы, особенно современные, растворяются в речи. В этом случае эффект исчезает, для чего использовалась пословица или поговорка.

Таким образом, в русских паремиях можно объективно заметить особенности национального мировоззрения. Первичное знание способствует улучшению простых слов с большим семантическим контекстом.

\section{Summary}

To summarize all of the above, I want to say that the study of proverbs and mishears in elementary school is an integral part of education. This knowledge helps to form the correct picture of the history of the language in students, to show its depth and beauty. Proverbs develop in children observation, speech, instinct for the sonic beauty of the language, sense of humor, enrich their knowledge of the world. In primary school, the work is reduced to the active acquaintance of students with proverbs, their memorization. The teacher should help children to reveal the meaning of proverbs and be able to apply them in their speech. The material proposed in this article is useful for working in elementary grades in language lessons and literary reading. 


\section{Литература}

Бромлей, Ю. В. Очерки теории этноса. Москва: Наука, 1983.

Даль, В. И. Пословиць и поговорки русского народа. Москва: Эксмо-Пресс, 2000.

Даль, В. И. Толковый словарь живого великорусского языка. T. 1-4. Москва: ГИИиНС, 1955.

Кабинетская, Т. Н. Изучение пословиц и поговорок в начальной школе: Методическое пособие. Псков: ПОИУУ, 1994.

Сысоев, В. Д. Пословищьы и поговорки. Москва: АСТ, 2009.

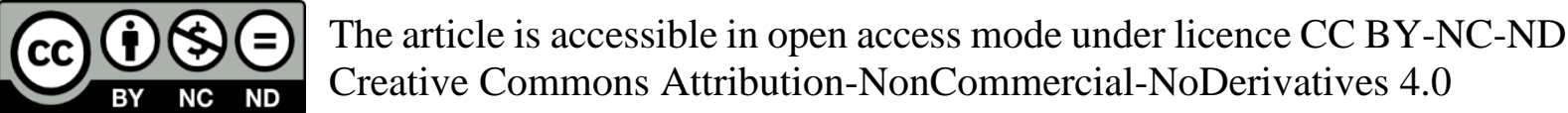

